\title{
Antiquization processes in the Macedonian, Kazakh and Turkmen National Narratives: Visual constructs that shape political conceptions
}

https://doi.org/10.1515/openps-2018-0008

received February 7, 2018; accepted October 15, 2018.

\begin{abstract}
The goal of this chapter is to conduct the analysis of the national symbols systems in the public space of Skopje (Macedonia), Astana (Kazakhstan) and Aşgabat (Turkmenistan) that are being represented in national political discourses along with a wide interpretation and contextualization in the framework of the postsocialist process of reconstruction of national symbolism in order to indicate identity and restoration structures and development of the actual national discourse in Macedonia, Kazakhstan and Turkmenistan.
\end{abstract}

In the actual process of reconstruction of national symbols system in analyzed cultural traditions it is important to underline the influence of nationalist ideology, which both in the Balkans and Central Asia has appeared in the form of ethno-nationalisms, where such factors as: language, history, culture and religion have been of crucial importance for construction of the idea of community that defined particular ethnos. One of the most influential tools of national ideology is taking the advantage of historical arguments aiming to expose the previous control over certain territory through the power structure, introduced by the present day nation.

Keywords: nationalism; monuments; antiquization; Kazakh; Turkmen; Macedonian identity.

\section{Introduction}

The goal of this chapter is to analyse the national systems of symbols in the public spaces of Skopje (Macedonia), Astana (Kazakhstan) and Aşgabat (Turkmenistan).

*Corresponding author: Agata Rogoś, Humboldt Universität zu Berlin / Uniwersytet im. Adama Mickiewicza w Poznaniu, E-mail: rogosaga@hu-berlin.de
These symbols are being presented in national political discourses together with a wide interpretation and contextualization in the context of the post-socialist processes of reconstruction of national symbolism in order to indicate identities and restoration structures within the development of the current national discourses in Macedonia, Kazakhstan and Turkmenistan.

A paradigm of the process aspiring to identity reconstruction has been deemed to include parallel national-identifying space-planning projects, marked with discourses of national self-definitions (see Zieliński 2002: 94) which include transformation of urban spaces and architectonic revitalization of city structures in the form of unified neoclassicism stylistics which refer to the aesthetics of power. The three analysed semantic models in this chapter (Skopje, Astana and Aşgabat) will serve as examples of the materialization of discourse based on the pattern of exposition of the national idea by referring to the main features of the process of nation-construction. Furthermore, the above-mentioned case studies clearly manifest the role of history and support the assumption that a nation is memory-based structure which, through the process of creation of its own narrative, can't exist beyond itself (Özkirimli 2005: 162-205, Brunnbauer 2013: 11).

Macedonian, Kazakh, and Turkmen ethno-cultural models might be defined as aesthetic and ideological constructs, in which a dominant role can be assigned to memory places (lieux de mémoire), which designate the frames of self-definition processes, legitimised by the presence of social and political actors (Nora 1998).

As noted by Ulf Brunnbauer, historians write national narratives, linguists create national languages, folklorists construct national cultures, and architects build national styles (Brunnbauer op. cit.: 9-37). All these components are used in the construction processes of national systems of symbols, present in the public space, with priority given to realization of the overall representation system to be inscribed in the general awareness and popular culture, which in turn can lead to its complete integration with a 
realistic, perceptible and transparent national symbolism (Löfgren 1989: 5-23).

In the actual process of reconstruction of national systems of symbols in the analysed cultural traditions it is important to underline the influence of nationalisms, which both in the Balkans and in Central Asia has appeared in the form of ethno-nationalisms, wherein factors like language, history, culture, and religion have been of crucial importance for construction of the idea of a community bonded by one ethnos. This influential tool of national ideology takes advantage of historical arguments, aiming to expose the previous control over a certain territory through the power structure introduced by the present day nation.

As claimed by Malkki (1992) and other scholars (i.e. Appadurai 1988, 1990, Said 1979, 1986, Clifford 1988) - "the metaphorical concept of having roots involves intimate linkages between people and place" (Malkki 1992: 24). It is implied mostly in a construct connecting three components: roots, identity and territory (territorialization). These processes has strongly emerged from the phenomenon of displacement and inventing category of a homeland in the absence of a territorial one through memories and corporeal distance. That implies also cultural displacement of people or domination of other cultural influences or cultural traditions that are incorporated in the current political systems. This status can create imagined boundaries at the centre and relegation of invisible peripheries, which can be acknowledged as a dynamic processes of ethno-political influences of dominant groups. Territorializing remains a very important factor not only in a search of the identity but also as a meaning of displacement in the process of rootedness that is deriving identity from the place. In these terms a group is referring to a genealogical tree that evokes temporal continuity of essence and territorial rootedness.

What we can refer to is a national geographic map present in a construct of the concept of nation and spatial arrangement of peoples and culture, which aims to conceptualize a space in general. As Gupta points out:

\footnotetext{
Our concepts of space have always fundamentally rested on ... images of break, rupture, and disjunction. The recognition of cultures, societies, nations, all in plural, is unproblematic exactly because there appears the unquestionable division, intrinsic discontinuity, between cultures, between societies (Gupta 1988: 1-2).
}

It can be pointed out that heroizing and romantic factors connected with the process of territotrialzation might appear as components of cultural identity. In all the constructs created by analysed discourses the issue of territory and rootedness is strongly connected with the concept of nation-building and the collapse of socialist orders creating a sort of national-socialism. As stated by Michael Billig in his essential study on nationalism "one might hypothesize that a whole complex of beliefs, assumptions, habits, representations and practices must also be reproduced. Moreover, this complex must be reproduced in a banally mundane way, for the world of nations is the everyday world, the familiar terrain of contemporary times" (Billig 1995, 6).

What I attempt to analyse in this paper are the ideological habits, by which certain nations are being reproduced as nations and I will follow the concept of Billig (1995) to stretch the term nationalism so that it covers ideological means by which nation-states are being represented (idem). In analyzing contemporary process of reconstructing national narratives in the post-socialist states, the role of national ideology should be underlined. It appeared in the form of unification announcing the concept of defining a nationality dominated by the constitution of state institutions (Brubaker 1997: 2). Another element important for the analysis of national narratives in Macedonia, Kazahstan and Turkmenistan is the insight in post-socialist reality from the perspective of the development of uncontrolled ethno-nationalism, which often appropriated national-centered perspective, where factors such as language, history, culture and religion were of key importance in shaping of the idea of national community. However, it should be emphasized after Brubaker that nationalism is not shaped by the concept of nation (Brubaker op cit. 17), but is produced or induced by political fields ${ }^{1}$ (cf. Bourdieu 2001).

A significant argument of ethno-nationalism is the use of history in order to illustrate the former control over a given territory by the power structure that the modern nation is referring to. In the Balkan cultural area very often different nations refer to the same origin, while emphasizing their ethnocultural distinctiveness, an example of which is the Macedonian model of selfdefinition.

The impact of modern nationalism on Macedonian and its peoples has been momentous. It is one of the prime reasons for the area becoming the 'apple of discord' in the Balkans

1 Following Brubaker I will use the term political field in broad terms as proposed by Pierre Bourdieu, taking into consideration that other fields, economic and cultural, can generate the development of national ideas and movements, vide: Katherine Verdery Nationalism and National Sentiment in Post-socialist Romania, in: "Slavic Review" 52 (1993). 
and the centre of such intense controversy, which has continued unabated to the present and in the past has been responsible for much bloodshed. (...) It is seen as an activist ideological movement, which aims to unite all members of a given people on the basis of a putative shared culture. As such it claims to represent the whole collective, however defined, and is antagonistic to competing cultural claims on the totality or parts of this collective, which is deemed by the adherents to constitute an actual or potential nation (Poulton 1995: 6).

For the purpose of further considerations, the concept of Clifford Geertz will be adopted, formulated as "marking of all objects, acts, events, features or relations that become the notion of any concept" (Geertz 2005: 113); in Geertz's approach, it is the concept that defines the framework of the symbol. As Geertz further states, symbols are material representations of concepts, "abstractions compounded from experience and recorded in perceptible, visible forms, substantial embodiments of ideas, attitudes, judgments, longings or beliefs" (ib.). However, this kind of analysis in the area of symbolism of cultural acts does not mean abandoning social or political analysis. As a result, cultural patterns, otherwise referred to as symbol systems, constituting the basic subject of this text, will become at the same time "external sources of information" (Geertz op.cit.: 114), which stimulate the processes of social public behavior. In a universal sense, it can be concluded that all human behaviors and institutional activities bear symbolic marks. The system of symbols we learn in the area of our own culture allows for social creativity and individual idiosyncrasy (Kertzer 2010: 13). In other words, these are the systems of symbols that are the tools shaping ethnocultural significance of the surrounding reality. They allow us to interpret what we see and who we are, deconstruct chaos, create new structures of identity meanings.

Here we come to a very important element of political symbolism - the state itself - which according to the concept of Michael Waltzer is invisible: to see it - it has to be personified, to love it - symbolized and to conceive it - imagined (Walzer 1967: 194). The modern symbolic political concept based on this kind of suppositions often leads to the conviction of the historical, dating back to antiquity, existence of nation-states and distinct nationalities. In a similar way, Benedict Anderson defines the nation as an "imagined political community", where national symbolism are not a decor of reality - a nation, but are a material from which nations were born (Anderson 1983: 14-15). Ernest Gellner perceives the idea of the state a bit differently, based on the concept of Max Weber, who treated the state as a "social action that has a monopoly on the legitimate use of force" (Gellner 1991: 11). Therefore the state would be an institution or a set of institutions that deal with forcing of social order.

Whereas Walker Connor $(1972,1994)$ casts a completely different light on issues of nation and state, which he considers in antagonistic conceptual groups: the nation and nationalism, and the state and patriotism. The patriotic attitude, i.e. loyalty to the political and territorial unit, which is the state, is opposed to ethno-nationalist processes understood as a psychological bond of the origin of the group (nation).

In view of the concepts cited above, it is worth paying attention to the solution offered by Anthony Smith, namely the division into national-state, which is understood as a "state sanctioned by the principles of nationalism, which members show a certain degree of national unity and integration (but not cultural homogeneity)" (Smith 2007: 30) and state-nation, where multiethnic states strive to achieve a national structure, moving through adaptation and integration to form a homogeneous, though not homogeneous, nation. Very often we can observe the process of transition from one form to another, the first category being marked by strong radicalism, very often deprived from an integration factor, in the place of which an exclusive element appears. In the case of the analysis of national narratives in contemporary Macedonia, Kazakhstan and Turkmenistan, I will perceive the process of building national identity as a performative act that takes place in the sphere of artifacts - in a dynamic and undefined ways.

The nationalist concept of the nation presupposes a precise definition of the function of the nation, which in the nationalistic approach resulted from the earlier existence of a community that differentiated itself from the Other. An important category of the nation or nationality in the context of the discussed research problem introduces Rogers Brubaker (1997) in his three-fold concept based on the configuration of nationalizing states, national minorities and external national "homelands". The categorization presented by Brubaker is particularly important for the analysis of the Macedonian question from the perspective of Macedonian (Slavic) and Albanian (non-Slavonic) discourses, but can be also adopted in case studies of Kazakh and Turkmen discourses dominated by the post-Soviet and ethnically indigenous influences. Brubaker draws attention to the ambivalent status of members of the community, belonging to the place of residence and the status of formal citizenship in one state, as well as the ethno-national relationship in relation to the Other (Brubaker op cit. 56).

In conclusion, the definitions of the nation oscillate between those that accent objective factors - such as 
language, religion, customs, territory and institutions, and those that emphasize purely subjective factors - such as behaviours, views and feelings (Smith 1999: 23). In this way appears a threat which makes it very difficult to separate nations from other forms of the community. A consolidation method based on the selection of criteria combining objective and subjective elements has been adopted, but they have not produced a satisfactory scientific consensus. One issue is, however, unquestionable, namely that the nation is not identical with a state constituting a set of autonomous institutions located in a given territory, nor with an ethnic community that usually has no political design, public culture, and in many cases also no territorial dimension.

For the purposes of this analysis, the definition proposed by Anthony Smith seems to be the most adequate, which describes the nation as a "defined human community, inhabiting the native land, having common myths and common history, common public culture, one economy, as well as rights and duties common to all members" (Smith op cit. 25). The functioning of the national model proposed by Smith leads to the absolutization of the national idea and the reification of certain ranges of national culture:

When such practices are raised to the status of symbols and shifted to the nationalist discourse, their significance changes. Nationalism uses alleged traditional ethnic symbols to stimulate reflection on its own cultural distinctiveness and, in a consequence, to shape a sense of national belonging. Nationalism reifies those aspects of its own culture that enable people to talk about it in a way that it would be something unchangeable (Eriksen 2013: 155-156).

Anthony Smith valorises national symbols that "give concrete meaning and visibility to the abstraction of nationalism. Representations and images of the nation produce a huge influence on people" (Smith op cit. 80). National symbols are strongly subordinated to the context and sense of community, they can be both exclusive and inclusive in character. They are such a deeply absorbed element of everyday life in every cultural tradition that it is often difficult to refer to the actual history and see that they are not natural but conventional signs and that national identity is a construct, not a natural right of a given country.

Moreover it should be noted that national symbols are not requisites connected with a particular cultural tradition, which give an aspect of eternally "ancient" tradition, which yet can be referred to. As Geisler states, they are rather illustrations of "invented traditions" created by artists and intellectual elites over the last three centuries, being constructs of modernity (Geisler op cit. XXIII), supporting and sanctioning the considerations of Hobsbawm (2010) and Anderson (1983) who perceive the nation as a relatively young and socially motivated phenomenon.

From the perspective of contemporary national Macedonian or Turkmen discourse, national symbols are transformed into elusive cultural "macros" that maintain historical references in the architectural structure, indicating not only permanent or temporary triumphs, but also under their surface we find various discourses and contestations that they have crystallized around these symbols throughout the centuries. National symbols abstracted from their natural structure, embedded in political rhetoric, show not only the contestation of their meaning, but also the historical struggle between hegemonic forces, expressed through various practices of choice and meaning in time (Geisler op cit. XXXI).

\section{Antiquization process - general remarks}

Interpretation of images is based on two types of methodological tools: contextualization of objects in the socio-cultural process and the analysis of symbolic phenomena constructed by the system of national myths, which, following Dan Sperber, is not treated as a system of signs, as a result they do not connect with their interpretations as a code (Sperber 1975: 84), but exist as conceptual representations that describe or interpret them (ib.: 112). Referring to the concept of Gadamer, who distinguishes artificial and natural symbols, while images depicting artificial symbols do not owe their real meaning to the act of "unveiling" or inaugurating:

Meaning is not given by the public act of sacrifice or unveiling, thanks to which the work obtains a specific predestination. It happens rather that before it is given the function of a monument, it is already a product of its own semantic function as a pictorial or non-pictorial representation (Gadamer 1993: 166).

The significance and influence of the image cannot be limited to the period before its inauguration only, but it is necessary to distinguish the function of signifiant and signifier that is prior to the implementation of the image in the public discourse. The moment of making the image public is very important in the entire representational and symbolic process, because it activates perception and 
deepens the meaning of the image itself, contextualizing it in the physical socio-cultural space.

In the process of analysing the functioning of symbols in the context of political and cultural discourse, a very important issue is the phenomenon of iconoclasm understood in a broader sense, motivated by issues of political nature, as is the interpreted case studies. In Freedberg's opinion, it is both the oldest and the newest form of iconoclasm, that sets up a clear political goal.

\footnotetext{
The goal is to overthrow everything what symbolizes - indicates - an old and usually repressive order that wants to be replaced by a new and better one. The visible testimonies of a bad past are thus removed. The overthrow of the images of the rejected system, or the authoritarian and hated governments, means forgetting the past and starting to realize the promise of utopia (Freedberg op cit. 395).
}

The political iconoclasm in analyzed case studies does not however take only the form of castration of the material monuments of the previous system, but the elimination of the entire historical and cultural structure, thus introducing a completely new historiographic narrative, which leads further to the reconstruction of the selfdefinition processes and the redefinition of the broadly understood cultural iconosphere. That is why I will be inclined towards Freedberg's idea that the political iconoclasm is something more than the removal of the symbols of the hated Other (Freedberg op cit. 395).

In his analysis of architecture and self-definition processes, Lawrence J. Vale notices that both objects and events (rituals), as well as monuments and ceremonies all these elements co-create and form a significant symbol system conducive to the processes of constructing and consolidating the collective We (Vale 2008: 52). Symbolic elements of public space reconstruction become cultural tools that strengthen the extensive process of redefinition of collective identity or, in other words, the unification of self-definition processes based on a homogeneous historiographic vision referring to the valorisation of the distant past. In this way, the newly sanctioned collective image of the nation will find not only symbolic but also material expression in the new spatial and ethno-spatial order. The urban plan of the "new" city is primarily the self-definition layer, which serves the symbolic transfer of ideology of power and imagines the construct of a national or mono-national state. This type of representation, which embodies the aesthetics and transformation of the space chosen or imposed by the political elite and the apparatus of power, and not by society, as a result the place generated in this way only in a small extent reflect the natural national identity. In this case, architecture becomes a tool for popularizing the set of values and a complex image of the mythologized cultural tradition defined as a national identity.

We are now facing an important question - how the cultural and spatial policy in young states constructs a relationship between national and subnational (transnational) identity and the place of construct of the Other in relation to the autochthonism of one group and the influx of the other. In this context, the case of Macedonia and Turkmenistan are very rich in research material (artifacts and changes taking place in urban space), especially when we look at spatial transformations from a historical perspective and treat the architectural and urban layout of the city and ethnogeography as an element of the symbolic self-definition construction.

Over historical periods architecture has been a tool for strengthening and implementing authority of power, through adequate symbolism and formal means, a unitary national construct, which was identified with a given regime (power) both politically and iconographically, using a homogenous style and formal means to facilitate aesthetic and symbolic communication, as noted by Lawrence J. Vale:

Architecture and urban design may be used as an iconographical bridge between preferred epochs, joining the misty palisades of some golden age to the hazy shores of some future promise by neatly spanning all troubled colonial waters (Vale op. cit.: 55-56).

The phenomena of the transformation of space and the symbolic marking of the city in the case of interpreted identification processes, they will serve as paradigms for the consideration of the relationship between architecture and spatial construction of the city (capital) and power and construction of national identity, which remains one of the most obvious examples of such processes.

In this approach, architecture is often a tool used by rulers and leaders to control and build identity and unification constructs - mechanisms that are possible thanks to its psycho-perceptive determinants - such as seduction, impressiveness and intimidation. It is enough to cite two symbolic acts based on the relation of history, architecture and power, which refer to the universal strategy of exposing strength with the use of visual elements and iconography of authority, such as the architectural travesty made by Mussolini in the 1920s thanks to the idea of building "Third Rome" in reference to the glorified ancient history or Berlin from the times of the "Third Reich", but also the reclamation of Athens as the Greek capital (1834), which suggest that 
the processes of ideological and aesthetic historization referred not only to the sacralization of the historical and national idea in the search for a myth about origin in the distant past, but also related to the use of the preferred formal and architectural style. It can be hypothesized that the lack of stylistic consistency and the construction of its own aesthetic construct was the dominant feature of all totalitarian assumptions transforming the urban structure, which treated architecture and aesthetic expression as components in the formation of anatomy of power.

The recurrence of components of classical architecture is a phenomenon that can be observed over the centuries, from the Renaissance until contemporary times. In this paper I draw attention to the way of reinterpreting classical architecture and the ideological factors that are associated with it, defined by historians of architecture as the phenomenon of antiquization (Tzonis and Lefaivre 1987). These rebirth practices, present in the process of transformation of the public space are determined by shaping a city into the form of, e.g. Ancient Rome, or Athens, in order to implement the structural order in the spirit of classicism. The process of prescription of antiquity usually has a temporal character, like cérémonies à l'antique - public events of a political nature, often transformed into permanent aesthetic reconstructions (Tzonis i Lefaivre op.cit.: 263). One of the reasons for the process of urban transformation in the form of antiquization, as stated by Tzonis and Lefaivre, is the act of politicization of a despotic state machinery, to indicate the legitimacy of power that is associated with the process of internal colonization of the urban zone.

However, such acts of urban and social identity reconstruction not only eliminate, but in some cases escalate the level of conflict within a group operating in a given symbolic and semantic space. As it is seen in the cases of Skopje, Astana and Aşgabat, the process of antiquization is not only an act of contradiction, i.e. imposing a new order by one group (in political, ethnic or cultural spheres), but becomes a process; one in which buildings are competing against each other. In this case the philosophy of classical architecture of antiquity, connected with the concept of temenos - meaning a world free from contradictions and based on pure principles of symmetry and balance - is exposed to a misleading interpretation and distortion of the ideas hidden behind this construct.

Antiquization aims at introducing analogies in the perception of the viewer between ancient regimes and contemporary political forces, legitimizing them by similarity (Tzonis and Lefaivre op.cit.) and using classical architecture for different interpretative meanings and functions. To name just a couple of the most significant examples of antiquization in modern history, one might refer to the use of neoclassical elements in Fascist, Nazi, and Soviet-era Stalinism.

The most common attribute of antiquization is the formula of 'architectural quotation', which is expressed not only through the "classicism" of kitsch, commercial products, and propaganda, but also through ambitious and prestigious examples of architecture, so-called "postmodern buildings". They are often expressed in 'quotes' detached from the entirety of elements of classical architecture, and constitute foreign elements on the body of the building or the entire architectural structure within which they function. The above-mentioned ideologicalformal processes make a building as a simulacra of reality, a scenography space instead of a masked reality (Tzonis and Lefaivre op.cit.: 275).

The process of antiquization represents one of the most fundamental forms of defining the essence of the spatial transformations in Skopje, Astana, and Assgabat in the early $21^{\text {st }}$ century within the context of socio-cultural transformations, influencing the formal systemic structure and referring to the construction of the institutional power apparatus.

An attempt was made to present within the theoretical relations between the components of national ideology based on three fundamental symbolic constructs: nation, language and state, which in effect constitute a system of national symbols in a given cultural tradition. In modern post-socialist discourses of the analyzed case studies, along with the development of the young state, the semantic and symbolic framework evokes the nation's structure by valorizing the distant past and underlining selected historical arguments that aim to establish the ethno-cultural identity.

Even though from the first glimpse the comparative analysis of three case studies of Macedonian, Kazakh and Turkmen nation-building processes expressed through antiquization of public space and power-driven reinterpretation of history might differentiate in cultural backgrounds, there can be found similar patterns and mechanisms of interpretation. Although the different cultural backgrounds should be underlined, and those differences in nation-building processes might even strengthen the proposed model of interpretation.

What can distinguish Turkmen and Kazakh selfdefinition process from the post-Yugoslav Macedonian model is a strong impact of Soviet education and ideology that was being mixed with traditional ethnic lifestyles - both on the level of linguistic landscape and material 
culture production. Soviet cultural tradition was the domination of the Other upon the indigenous tradition of Kazakhs and Turkmens that influenced the construction of new state symbols. After the fall down of Soviet order one can observe the retooling to adopt the realities of a postSoviet jumble of nationalism, Islam, market socialism and authoritarianism.

On the other hand Macedonian case study might be perceived as a softer example of the symbolic domination of the Other, but on the other hand it bears a cultural and symbolic struggle between two dominant ethnic groups - Slavic and non-Slavic (Macedonian and Albanian) determinants of Macedonian identity discourse. In this case study the antiquization process is more connected to the performance of domination of one ethnic group than a battle between two different ideological systems, as might be observed on the Kazakh and Turkmen case studies. However three presented examples of the process of antiquization of the public space of capitals refer to the same interpretation model embedded in the territorialisation of identity discourse and rootedness of a particular dominant cultural tradition.

This psychology of space constructs, in a very clear manner, the relationship between individuals and the undetermined, immaterial power body. In this context, one might speak of different categories of space, dehumanization of architecture, and last but not least of different views on ethno-national discourse. If we agree that "nation" in terms of national ideology has been understood, to quote Anderson (1983), as an "imagined community", i.e. an entirely anonymous structure composed of unconsolidated elements, apart from abstract and imposed categories of community; and if we combine this with a power structure which is far from a real body and is established as ubiquitous power and a discipline construct (Foucault 1980), then a social order that is imagined as a spatial structure based on classical values in architecture will be achieved.

\section{Skopje antiquization process - disputing the socialist tradition}

In the case of the symbolic reconstruction of Skopje ("Skopje 2014"), it seems appropriate to follow up on the concept proposed by Rozita Dimova (2013), who claims that in this case one should not speak of a historical baroque style, which appeared in Europe in the particular social, political and cultural context of the Counter-
Reformation between the $16^{\text {th }}$ and $18^{\text {th }}$ centuries, but of an expressive and distinct mechanism that "serves as a powerful narrative of cultural experience, useful for dissolving the previous distinctions of ethnic, social and cultural identity, rural and provincial characteristics of collective life and subjectivity" (Lambert 2004: 12).

A comprehensive reconstruction of the urban space of Skopje relies on the new aesthetics, extraneous for this cultural area, that refers to the past and the historicization of public discourse, which has been imposed by the political elites. The new symbolic structures find themselves in-between historical heritage and contemporary political-economical reality, and become accelerators of social differences and ethnic conflicts, causing social antagonisms. The main part of the urban reconstruction project in Skopje consists of elements of Eurocentric and Christian-centric discourses that cause the Macedonian self-definition process to approach an exclusivist model, based on the phenomenon of historicization and antiquization of the urban (material) space and socio-cultural (symbolic) area.

The urban transformations of Skopje might be defined as the spatial collection of artefacts directed towards the process of exclusion and rejection, assuming that its essence is a state of symbolic conflict both in the internal semantic structure and through antagonisms acting in the field of external discourses. The construct created by the spatial and aesthetic transformation bears the markers of exclusion of the Other, formed on the basis of a political discourse, not only in the semantic area, but also in the spatial policy of the city, which is based on the development of its southern axis and symbolic separation of the northern part, which at the time of the Ottoman Empire constituted the heart of the city. Thus, we face a phenomenon of contestation, which is associated not only with the rejection of the earlier Ottoman-oriental tradition (and continuation of the process of de-Balkanization), but also with questioning the Yugoslav (socialist) tradition. In this kind of discourse-construction, based on the negative factor of exclusion, a semantic confrontational construct arises, which refers to the contradictory visions of the historiography concerning the origin of the Macedonian nation, and leads to the symbolic conflict of the public space. Those elements that function in social "reading" of the city in terms of division, contestation and conflict, as stated by Rozita Dimova (op.cit.) are based on antagonisms between individual images of "Us" and "Them", and create dynamic categories which are subjected to constant semantic and socio-cultural transformations.

The construction of the new symbol system in

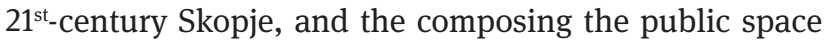


with an extraordinary amount of monumental sculptures, suggests the idea that the "new" city expresses a spectacular effort to transform the public space into a museum (Čausidis 2013: 41; Marina 2013; Janev 2015: 111). Museums, according to Timothy Luke, have the power of formulating collective values and social understanding (Luke 2002: xiii). The role of a museum is not limited to the production of a specific narrative, but is intended to support self-definition processes or the representation of collective memory, and under certain circumstances it may also take on the role of an active actor in the design of a common identity. This instrumental definition of a museum includes its figurative depiction as referred to by Nikos Čausidis, who speaks about the displacement of the function of an exhibition institution to that of a public space, in which the historical displays are subjected to the symbolic and physical translocation from museums (a public space governed by certain rules), which has led to the historicization of the institution of state and the "museification" of the city-symbol (Čausidis op.cit.: 36-37).

The described process of public space development in Skopje, created by the system of cultural symbols and social practices, has led to the creation of cultural heritage sites that were proffered as, in the case of the "Skopje 2014" project, the realization of certain components of ethnonational narratives and the symbolic reorganization of public space as part of the process of creating their own variant of the past in order to highlight the 'correct' history of Macedonia (Janev op.cit.: 111; Kolozova 2013; Vilić 2013). As Goran Janev notes, the new image of Skopje must look old enough to forget those elements of the past which cannot fit into the new national narrative (Janev op.cit.: 112).

This ethno-national narrative, constructed in the patriotic, traditional and national-romantic urban planning of "Skopje 2014", is based on contradictory semantic categories - on the one hand it refers to the Balkan autochtony of the Macedonian people (whether Slavonic or Antique), while on the other hand is expressed by aesthetics referring to the splendour and luxury of European urban centres.

The ethnocratic regime in Macedonia seeks to introduce symbolic divisions in the city, resulting from its ethnic affiliation in the spirit of essentialism, characteristic for this sort of power performance, thus arranging the public space in this particular way while at the same time confirming inter-ethnic antagonisms. Another tool for breaking up with former systems of representation and the topoi of a place is the imposition of an artificial layer of Europeanism upon Ottoman or Yugoslav modernism structures, which is designed to testify to the continuation of European civilization in this area while at the same time establishing a myth of antique origin.

Many analysts and researchers (Čausidis op.cit.; Janev op.cit.; Kolozova op.cit.; Vilić op.cit.) see the decisive role of politics present in the construction of the new national narrative, which aims to approximate a specific version of history based on the assumptions of ethno-national ideology. However, as aptly noted by Goran Janev "one can forget that history is inscribed in the city landscape" (cf. Gould and Silverman 2013). The history and memory of space, besides the discussed "Skopje 2014" project, create a polyphonic construct that is subjected to reinterpretation and recombination in social practices, while at the same time counterbalancing the structure of monumental artefacts and the artificially-implemented historicization process, situated in the multi-ethnic, multi-religious, and multilingual Macedonian reality.

\section{Kazakh state-building and the de-sovietization process on the edge of postmodernism and historicization}

Similar to Macedonian case study of symbolic and spatial transformations and the reconstruction of post-socialist urbanism, the process of antiquization of the public space also appears in the two former Soviet republics of Kazakhstan (Astana) and Turkmenistan (Aşgabat). Owing to the process of de-Sovietiziation of the public space, these two examples have many common elements that are also characteristic for analysis of the Macedonian case study. In Kazakhstan, the process of construction of the nation and its new identity was associated with the translocation of the capital and the construction of a completely new system of symbols and demarcation of the political space after 1997. The creation of a new state within the complex self-definition processes, including not only a post-Soviet legacy but also a significant group of ethnic Russians, was associated with an intense process of construction of the nation within the complex internal (sub-ethnic) elements of that identity (Schatz 2003).

The moving of the capital of Kazakhstan to Astana was also a symbolic act, aimed at consolidating inter-ethnic relations in the newly established state, thus enabling the newly constructed Kazakh identity to cover the largest number of ethnic groups living in Kazakhstan. It has been observed that: "Astana - like other newly created capital, 
which may otherwise seem unclear constructs - strongly supported the program of the ruling elites" (Vale 2004: 154).

The comprehensive image of a dynamically developing city has been marked by the symbolic picture of a Kazakh state that has been in the process of being constructed since the late 1990s. Nazarbayev, the president of Kazakhstan, has replaced all the monuments and street names originating from the time of Soviet Union with new artefacts and structures, symbolizing the break with the previous tradition and strengthening the new Eurasian identity of the Kazakh State. Many of the Soviet institutions and edifices were exposed to reconstruction processes, taking into consideration the - entirely new for the Kazakh context - aesthetical forms of postmodernism (Vale, ibidem).

The symptom of national ideologies that seems to be contradictory - mostly on the aesthetical level - in relation to the futuristic urban structure of Astana is a sculptural composition of the monument/column Kazakh Eli (The Kazakh State), which constitutes a particularly interesting artefact of the sculpture monumental forms that are referred in this paper in the broader context of the Kazakh, Turkmen, and Macedonian case studies.

The monument was created to represent and symbolize such notions as freedom, pride and the future of the Kazakh nation (Kopbayeva 2013: 810). The main element of the sculptural form is composed of a 91-meter high column, crowned with a stele representing the mythic figure of a golden bird - Samruk, the symbol of hope and freedom - which was meant to symbolize, through the proposed dimensions, the date of the independence of Kazakhstan (1991). In the inner structure of the monument are four relief compositions that are representative of the most important ethical values of the Kazakh nation. The presence of this monument, along with other examples of ethno-national constructs in other Kazakh cities as well - such as the statue of a golden man, Altin Adam, in Almata - indicate the existence of the components of the nation-building processes in the Kazakh ethno-national discourse, which are concentrated on the classical forms of expression which seem to be most restricted to nationalist ideologies.

\section{Turkmen past constructions and their antiquization narrative}

The cultural policy of Turkmenistan - Turkmenbaşi presents a distinct example of the transformation of the image of city space and construction of a new post-soviet national identity that refers to the ideologization of the public discourse, involving all spheres of social life. Unlike Astana or Skopje, when speaking of the construction of a new system of symbols in Assgabat what should be emphasized is the role of the cult of individual, or even the whole Turkmenbaşi family, which unites the new sociocultural and identity-based "architecture", integrating all the ideological aspects of the regime. The stylistic, formal and chronological analogies in constructing a new image of identity in Turkmenistan and Macedonia, as well as the closed models of representation of power through the construction of new self-definition processes, make it possible to identify a number of similarities between the two symbolic-semantic systems, which can be defined as a national brand identities (after: Omelicheva 2015: 92). This kind of self-definition construct, in which the common feature is the construction of a new identity in the conditions of a post-socialist rejection, the appearance of past narratives and related ideological and aesthetic constructs is characteristic for Central Asia i.e. Kazakhstan, Uzbekistan, Kyrgyzstan, and Turkmenistan, although the variability of this model, which makes it adaptable to other cultural traditions, cannot be excluded. The common point of these transformations is the construction of a new identity in the post-socialist conditions, along with the rejection, apparent in most of the cases, of the previous narrative and ideological-aesthetic construct attached to this tradition.

In the beginning of the 1990s, after the collapse of the Union of Soviet Socialist Republics, one of the most crucial elements of the ethno-cultural policy of the Turkmen state was the process of the "Turkmen cultural rebirth" (Akbarzadeh 1999: 272), which was designed to establish a new system of national symbols based on the revalorization of the distant historical narrative. The essence of the Turkmen ethno-cultural transformation project was constructed, apart from the language factor, with adherence to the clan-tribal tradition and the transnational character of the Muslim culture that contributed to the new ethno-national narrative. One of the most powerful apologists, and the constructor of the Turkmen-centred policy, was the first president of Turkmenistan after its independence - Saparmurat Niyazov (1990-2002).

In response to the need for construction of a new ethno-cultural identity of Turkmens after the collapse of the Soviet Union, a characteristic feature of this kind of process of nation building and nation branding in postcommunist societies can be observed.

The construction of the Turkmen system of symbols and a new ethno-national identity, in a similar way as in 
Macedonian national discourse, has been based on the sculptural-urbanism setting, consisting of outstanding monuments and enhanced by the dissemination of moral and spiritual values present in the cult of the individual (leader) and collected in the special codex Rukhnama the book of President Niyazov - which is a common social practice in totalitarian and post-totalitarian systems. Another analogy that emerges in the comparative study of Macedonian and Turkmen ethno-national discourse is the process of antiquization and a peculiar adherence to a national historiography, aimed at an apologetic valorisation of a distant past. ${ }^{2}$

The new official discourse of social practices, together with the new symbols and political rituals which took place in the first decade after the independence of Turkmenistan have been in fact supporting a political myth of an ethnically unified national state. As stated by Victoria Clement, discourses of the Turkmen national revival have been merged with the slogan - Altin Asir (golden century), which became a synonym for the prosperity that was supposed to prevail in the post-soviet Turkmenistan (Clement 2014: 550).

In the ethno-symbolic space of Turkmenistan, alongside the development of ethno-linguistic national ideas in the ethno-cultural discourse, a new image of the nation and its cultural tradition appeared. The main focus of the political elites involved in the construction of the new Turkmen identity in the post-Soviet reality have been concentrated, but have not been accumulated that much, on the mythologization and antiquization process of the ethno-genesis of a nation, such as on the language identity, which was aimed to constitute a crucial function in the self-definition process.

One of the first elements of the construction of artefacts for the new Turkmen identity, analogous to the Macedonian post-socialist ethno-cultural process, was a museum project and the reconstruction of the Gök-Tepe fortress - the memorial of the victory of Akhal Tekke Turkmens over the Russian troops in 1879, which exemplifies the symbol of Turkmen resistance against tsarist Russia (Akbarzadeh op.cit.: 273).

Another component of the symbolic system in Turkmenistan, visible after gaining independence from the influence of Soviet power, was the process of conversion of toponymy and street names, a process that was concentrated on the cultic figure of the new

2 In the Turkmen construct, the creators of the new historiography refer to the ruins of the ancient city Nisa, the first capitol of Parthian Empire, and monuments of Muslim culture and nomadic or shaman traditions (Omelicheva 2015: 100-102). leader - Saparmurat Niyazov, who proclaimed himself as Türmenbaşi (the leader of Turkmens). ${ }^{3}$ All the elements of the new urban structure of Assgabat, including a luxurious striving for an oriental and Muslim tradition and a system of symbols and figures of national heroes, were above all sealed with images of Türmenbaşi (Akbarzadeh op.cit.: 274). The artefacts of monumental forms that covered the space of Assgabat in the late 1990s were intended to create the awareness of the ethno-national rebirth and to construct the narrative on the origins of Turkmens, embedded in a distant, antique history and ethno-cultural tradition.

In the ethno-national discourse of Turkmenistan (parallel to the Macedonian discourse) the antique fatherland of Turkmens was identified with the contemporary territory of Turkmenistan via the main self-definition component of the Turkmen language, which is supposed to cover the whole geographical area of Turkmenistan, and also with the intensification of national ideology, which does not take into consideration the inherent language-identity differences.

The process of antiquization of Turkmenistan is located in the new Turkmen historical narrative, based on the tradition of the Parthian civilization, ${ }^{4}$ which enables the settlement of the Turkmen cultural tradition in antiquity. As a result, the Turkmen ethno-cultural discourse was reinforced with arguments appealing to archaeological and historical studies, which in turn have reinforced the position of political elites and supported the construct of a unified historically and ethno-genetically antique Turkmen tradition.

Similar as in the case study of the Macedonian symbolic construct, functioning since 1991 and realized by a strong component of antiquization, so too when analysing the Turkmen ethno-cultural landscape one might pose several arguments for the historical narrative, which refers to the logic of valorisation of the existence and functionalization of the present national states. Elements that have been used in the process of construction of the new Turkmen system of ethno-national symbols consist of details and fragments derived from the antique Parthian tradition, for example a sculptural detail placed on the top of the entrance to the building of Ministry of International

3 The choice of this terminology was intentionally chosen by president Niyazov, who with this symbolic act was referring to the old clan-tribal tradition of the Khans of Khiva and Bukhara, which was aimed to indicate the national unity of Turkmens and their connections to the ancient cultural traditions.

4 Research conducted by the Turkmen Academy of Science, inter alia by Kh. Yusupov, M. Durdyev (Akbarzadeh 1999: 280). 
Affairs and Education, representing monumental rhytons ${ }^{5}$ - a constitutive symbol of the Parthian tradition.

The complex of the monumental foundation, raised in the 1990s and at the beginning of $21^{\text {st }}$ century in Aşgabat, constitutes an important element in the Turkmen national discourse of the collective ritualization of the public space and social practices. In the semantic and formal analysis of the monumental architecture of Aşgabat, its convention, based on classical and symmetrical orders, in an analogous way as discussed in the previous case studies of Skopje and Astana, approximates the model of utilization of architecture for power's sake. On the other hand, the Turkmen construct differs from the other cases by its positioning of the present political leader as a national hero figure, along with a process of symbolic construction and sacralization that has determined the new image of the public space.

What the Astana and Aşgabat case studies have in common is their endeavour to construct a new national identity, together with their simultaneous rejection of the Soviet heritage and aspirations for a strong societal consolidation through the new system of symbols and national myths embedded in the ancient tradition, which in a certain schematic depiction brings these two cases close to the Macedonian project "Skopje 2014".

5 The Parthian empire came into being in Khorāsān during the reign of Seleucus I, 358-281 BC, following the absorption by the Parthians of the Parni (Dahae) tribesmen. The caravans traversing their territory brought them wealth and ideas from abroad. The figural art of the Hellenistic world made an especially strong impression on them. The finest Parthian objects come from Old Nisa, a town situated on the edge of the Karakoram Range, some 11 miles (18 kilometres) south of Ashkhabad in Tajikistan, close to the later town of New Nisa. Old Nisa was founded around $171 \mathrm{BC}$ by Mithradates I to serve as a royal Parthian residence and necropolis, as well as the kingdom's capital. It contained several fine temples and an impressive palace built around a vast central hall, the roof of which was upheld by wooden supports set in stone bases-a practice followed in the town's larger houses. Life-size clay statues of men and women stood between these supports. The royal treasuries contained many valuables, including silver and silver gilt statuettes of local Parthian deities and of Greek gods, bronze and iron weapons, burnished and painted pottery, glass, and cast bronze animals, such as griffins. The most significant of these treasures, however, is a series of ivory horn-shaped drinking vessels, or rhytons. Some are embellished with paste inlays and precious stones, and others have a carved frieze or band encircling their open ends. One rhyton (State Hermitage Museum) has a frieze of a procession that includes a Greek god. Conceived in the purest Hellenistic style, the frieze contrasts sharply with the rhyton's horned, lion-griffin-shaped terminal ornamentation, which is admirably modelled in the round, in accordance with the ScythoAltaic tradition, https://www.britannica.com/art/Central-Asian-arts/ Visual-arts\#toc13974, 30.06.2017.

\section{Conclusions}

Following the collapse of Yugoslavia and the parallel collapse of Soviet Union, a similar process took place in all former republics of the federation and in some former republics of the Soviet Union. It was characterised by the process of questioning not only the mechanisms and political structures, but also, or even mostly, by their aesthetics of nation-construction. The production of national symbolism was based on the construction of a new, previously non-existent national and state iconography, which has had an enormous political importance, as can be observed in a specifically dynamic manner in the examples of the Macedonian and Turkmen national systems of a symbols' construction process. The arrangement of systems of symbols (in all case studies) has been carried out in a complex external political context (relations with Greece, Bulgaria and Albania - together with their territorial and symbolic demands, or RussianTurkmen relations), as well as in a rather difficult internal situation, based on a multi-dimensional and sophisticated ethnic structure, leading in turn to contestation of the existing, multi-level aesthetic tradition.

There are essential questions that help to define the relationship between aesthetic language and the message/meaning which is attached to a particular representation (image). Is there any kind of architecture that is homogenously nationalistic or democratic? What form and aesthetic does abuilding take in a specific ideological context? Is it possible to find a structure of formal language, distinctive explicitly of totalitarian or democratic architecture? Are classical columns, simple forms based on the ancient order, attributable to the fascist or democratic architecture? Although it is not possible to find a definite model or artistic language that would define one kind of political message, the goal of this chapter has been to construct the exposition of political features through the creation of systems of symbols in the form of art and architecture aimed at shaping political conceptions.

A distinctive feature of the Nazi or Socialist Realist architecture, or any one that as a fundamental aim the exposition of force and power, is not determined that much by the particular stylistic form, but by the obsessive attitude towards scale, symmetry, and prevailing elements of system of symbols. Five-pointed stars, sickles and hammers, and sheaves of wheat in the case of socialist realism, or swastikas and eagles, or fasces in the context of Nazism or Fascism, and last but not least antiqueinspired symbols such as sun and lions in the case of popnationalism in Macedonia or Central Asia, were used in 
different forms, architectural plans, elevation elements, and details or large-scale sculptural elements.

The goal of analysing the three selected case studies focusing on the transformation of the systems of symbols in a post-socialist context, showing the symbiotic relation between architecture (system of representation) and power, was intended to point out the connections between architecture, power, and national identity construction processes, mostly in the light of national ideologies, which indicate the affection of architectural forms and large-scale sculptural structures in the process of political transformations.

\section{References}

Akbarzadeh, Sh. "National identity and political legitimacy in Turkmenistan.” Nationalities Papers 27 (1999): 271-290.

Anderson, B. Imagined Communities: Reflections on the Origin and Spread of Nationalism. London-New York: Verso, 1990.

Appadurai, A. 1988 Putting Hierarchy In Its Place. Cultural Anthropology 3(1):36-49.

1990 Disjuncture and Difference in the Global Cultural Economy. Public Culture 2(2): 1-24.

Billig M., 1995, Banal Nationalism, Sage.

Bourdieu P., 2001, Reguty sztuki. Geneza i struktura pola literackiego, Kraków: Universitas.

Brubaker R., 1997, Nationalism reframed: nationhood and the national question in the New Europe, Cambridge University Press.

Brunnbauer, U. The Ambigous Nation. Case Studies from Southeastern Europe in the 20th Century. (2013). Eds. Grandits, H. U. Brunnbauer, Munchen.

Clement, V. 2014, "Articulating national identity in Turkmenistan: inventing tradition through myth, cult and language." Nations and Nationalism 20 (3): 546-562.

Clifford, James 1988 The Predicament of Culture: Twentieth-Century Ethnography, Literature, and Art. Cambridge, Mass.: Harvard University Press.

Connor W., 1994, Ethnonationalism: The Quest for Understanding, Princeton University Press.

Čausidis N. "Proektot Skopje 2014: Skici za edno naredno istražuvanje.” (2013). Web. 10.01.2014 <http://www.okno.mk/ sites/default/files/082-Nikos-Chausidis-Skopje-2014.pdf〉.

Dimova, R. Ethno-Baroque: Materiality, Aesthetics, and Conflict in Modern-Day Macedonia. New York-London: Berghahn, 2013.

Eriksen T.H., 2013, Etniczność i nacjonalizm, Kraków: Wydawnictwo Uniwersytetu Jagiellońskiego.

Foucault, M. Power / Knowledge: selected interviews and other writings 1972-1977. New York, 1980.

Fraenkel, E. and Ch. Kramer. Eds. Language Contact: Language Conflict. Peter Lang Publishing, 1993.

Freedberg D., 2005, Potęga wizerunków. Studia z historii i teorii oddziaływania, Kraków: Wydawnictwo Uniwersytetu Jagiellońskiego.
Gadamer H.G., 1993, Prawda i metoda. Zarys hermeneutyki filozoficznej, Kraków.

Geertz C., 2005, Interpretacja kultur. Wybrane eseje, Kraków: Wydawnictwo Uniwersytetu Jagiellońskiego.

Geisler M.E., (red.) 2005, National Symbols, Fractured Identities: Contesting the National Narrative, University Press of New England.

Gellner E., 1991, Narody i nacjonalizm, Warszawa.

Gould R.M., and E.R. Silverman. "Stumbling Upon History: Collective Memory and the Urban Landscape”, Geojournal 78/5 (2013): 791-801.

Gupta, A., 1988, Space and Time in the Politics of Culture. Paper presented at the 87th Annual

Meeting of the American Anthropological Association, Phoenix, Arizona.

Hosling, G. and G. Schöpflin. Eds. Myths and nationhood. New York: Routledge, 1997.

Janev G. "Skopje 2014: Erasing Memories, Building History." (2015). Balkan Heritages: Negotiating History and Culture. Eds. Couroucli M. and T. Marinov, Routledge.

Kertzer D., 2010, Rytuat, polityka i władza, Warszawa.

King, R. Minorities under Communism Nationalities as a Source of Tension among Balkan Communist States. Cambridge, 1973.

Kolozova K. "Skopje 2014 Project and its Effects on the Perception of Macedonian Identity Among the Citizens of Skopje: Policy Brief." (2013). Skopje: Institute of Social Sciences and Humanities. Web. 11.06.2016 <http://isshs.edu.mk/ documents/1.-Sk2014-ENG.pdf>.

Kopbayeva D. "Is Astana a Nationalistic Project? The Role of Kazakhstan's New Capital in Development of the National Identity", 1st Annual International Interdisciplinary Conference, AlIC. (2013). Web. 12.06.2016. <http://eujournal.org/index. php/esj/article/viewFile/1400/1409>.

Lambert, G. The Return of the Baroque in Modern Culture. London: Continuum, 2004.

Löfgren, 0. "The Nationalization of Culture." Ethnologia Europaea: Journal of European Ethnology Vol. XIX (1989): 5-24.

Luke T. W. Museum Politics. Power Plays at the Exhibition, University of Minnesota Press, 2002.

Malkki L. National Geographic: The Rooting of Peoples and the Territorialization of National Identity among Scholars and Refugees, in: "Cultural Anthropology", Vol. 7, No. 1, Space, Identity, and the Politics of Difference. (Feb., 1992), pp. 24-44.

Marina O. "Skopje, Great, Greater, Grandeur: City between Solidarity and Exclusivity." MONU, Greater Urbanism 19 (2013): 76-81.

Neofotistos, P. V. The risk of war. Everyday sociality in the Republic of Macedonia. University of Pennsylvania Press, 2012.

Nora, P. Eds. Realms of Memory. (trans). A. Goldhammer, New York: Columbia University Press, 1998.

Omelicheva, M. Y. Eds. Nationalism and Identity Construction in Central Asia Dimensions, Dynamics, and Directions. Lanham: Lexington Books, 2015.

Özkirimli, U. Contemporary Debates on Nationalism: A Critical Engagement. Palgrave Macmillan, 2005.

Said, E. 1979 Zionism from the Standpoint of Its Victims. Social Text 1:7-58.

Said, E. 1986 After the Last Sky. Palestinian Lives. New York: Pantheon. 
Smith D. A. National Identity. University of Nevada Press, 1991.

Smith D. A. Myths and Memories of the Nation. Oxford University Press, 1999.

Smith D.A., 2007, Nacjonalizm. Teoria, historia, ideologia, Warszawa.

Schatz E. Modern Clan Politics: The Power of "Blood" in Kazakhstan and Beyond. Seattle: University of Washigton Press, 2003.

Sperber D., 1975, Rethinking Symbolism, Cambridge University Press.

Tzonis A. and L. Lefaivre. Classical Architecture: The Poetics of Order, MIT Press: Cambridge, 1987.

Vale, L. J. Architecture, Power, and National Identity. Yale: University Press, 2008.

Vangeli, A. "Nation-building ancient Macedonian style: the origins and the effects of the so-called antiquization in Macedonia." Nationalities Papers Vol. 39, No. 1 (2011): 13-32.

Vilić N. "Disenzusni kontinuitet sećanja”, Arhitektura 178 (2013): 14-19.

Walzer M. 1967, On the Role of Symbolism in Political Thought, w: „Political Science Quarterly”, 82, (2), s. 191-204.

Zieliński, B. Eds. Wokót Macedonii: siła kultury - kultura sity. Poznań: Wydawnictwo Naukowe Uniwersytetu im. Adama Mickiewicza, 2002.

Žižek S. and A. Hamza. From Myth to Symptom. The case of Kosovo. Prishtinë, 2013. 